\title{
A Survey on Hybrid Renewable Energy System for Standalone and Grid Connected Applications: Types, Storage Options, Trends for Research and Control Strategies
}

\author{
ASHWANI KUMAR(1), V.M.MISHRA(2), RAKESH RANJAN(3) \\ 1Research Scholar, Department of Electrical Engineering, Uktech University Dehradun, INDIA \\ 2Associate Professor \& Head, GBPEC, Pauri Garhwal, INDIA \\ 3Director-Principal, IITB, Jhundpur, INDIA
}

\begin{abstract}
This article presents an critical review on various issue concerning to HRES like types, storage, trends for research and control strategies of HRES. Various interconnection techniques for HRES are presented. It has been made a short review of Mathematical model for renewable energy sources. Conclusion and result of control strategies work of HRES, Storage techniques of HRES for energy flow management is presented. Finally, it has been made a summary of the future analysis, challenges in techniques and improvements of HRES based power generation techniques for Isolated and grid connected applications.
\end{abstract}

Keywords - Renewable energy, hybrid power system, control strategies.

Received: June 20, 2019. Revised: March 13, 2020. Accepted: April 27, 2020. Published: May $28,2020$.

\section{Introduction}

There is no reason to doubt that in the future our existence will be more and more dependent upon the energy. Specially in developing countries energy condition are improved by renewable energy sources from last many year. And for conventional source it becomes difficult to match increase demand of electricity. Renewable energy source generally does not require fuel and mostly eco-friendly but it is fluctuating in nature. Difficulty in availability and remoteness makes conveyance of sustainable energy sources costly. Grid extension is also not cost effective [1]. Sustainable source are the optimal outcome to provide power in remote zones. Also to meet the energy requirement locally available energy source is best.

Various researchers proposed renewable hybrid power system to supply the remote areas. there are various sources like PV, wind, biomass, fuel cell which can be utilized for power production[2]. HRES has been advised by different explorer to supply electricity in distant zones. To achieve reliability of supply combination with rechargeable batteries for energy supply system during peak load periods and operation with some other kind of generator is considered for isolated utilization. These arrangements are permanently provided along with storage option to rectify the unreliable manner of sustainable energy genesis like PV and Fuel [3].

Control strategies are the backbone of HRES that perform the communication and passes the information together with several elements of structure. Control strategies modifies the result of sustainable energy sources and in addition schedules the storage and load connected to grid. This limits the storage option and protect it [4].Whenever extra energy is accessible, it is feeded to storage cells to stock the extra energy. When demand is more than supply then stored energy is utilized [5].But some times it is required to connect conventional energy source with RES to bear the load [6].

This Paper imparts a survey on different issue related to HRES in isolated approach, types, storage, trends for research and control strategies of HRES.

\section{Integration Scheme}

There are following basic arrangement to integrate distinct sustainable energy provenance like, DC linked scheme, AC linked scheme, Hybrid linked scheme [7].

\section{A. Stand-alone hybrid systems}

There are two design of Stand-alone hybrid systems, dc link bus and centralized ac linked bus system. In this system all the power and storage device, and burden are linked to a dc link bus by means of suitable equipments as shown in fig $2.1[8,9]$.

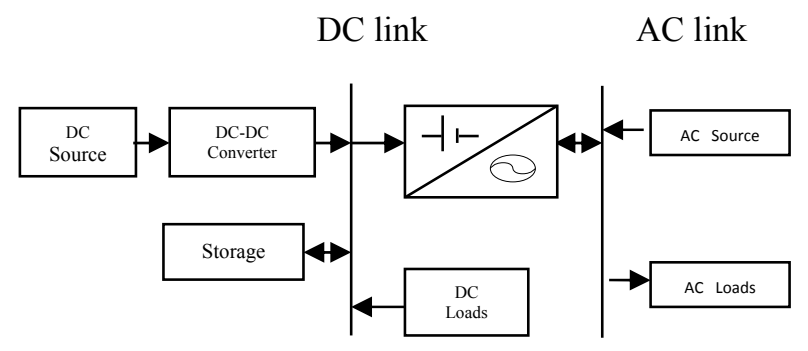

Fig 2.1 DC Bus

Also in ac link scheme, the energy producer, storage cells, and loads are linked to an ac link bus by means of suitable power electronic equipments as depicted in fig.2.2. It is advance structure, which provides the increasing energy needs [10].

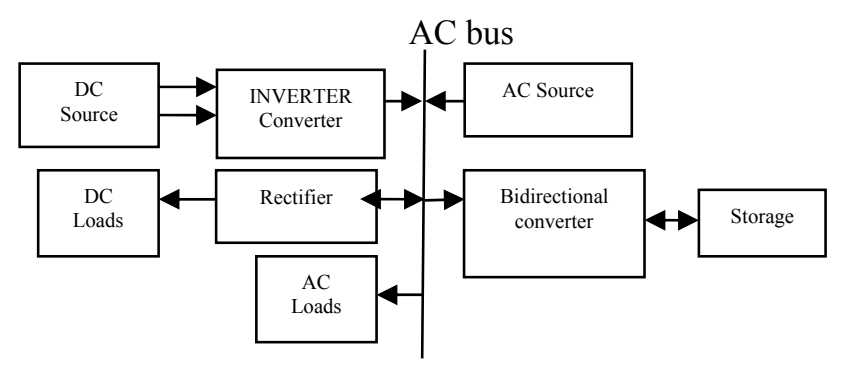

Fig 2.2 AC Series 
In parallel scheme the ac genesis and different loads are right away coupled to ac linked bus as shown in fig.2.3 [11, $12]$.Such scheme makes system robust and insure reliability.

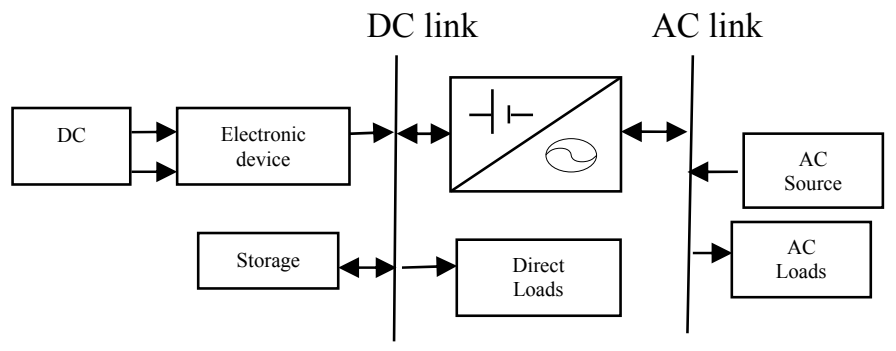

Fig 2.3 Parallel

In distributed configuration there is restriction for connection of single source to the load at a particular case as shown in fig. 2.4 [13].

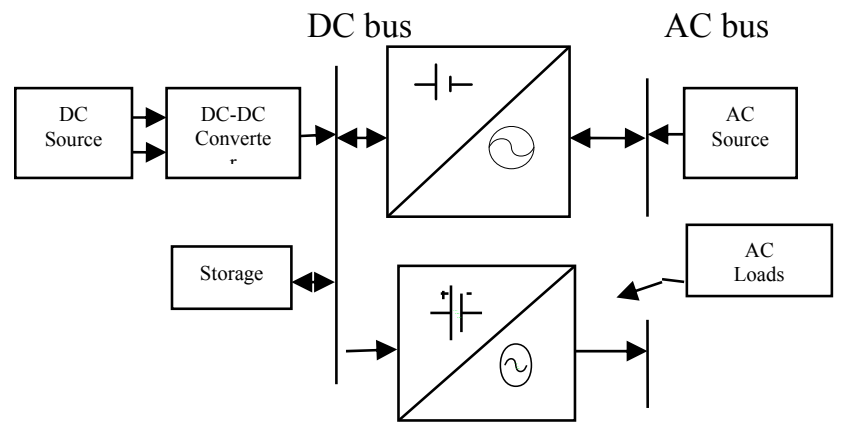

Fig 2.4 Distributed stand-alone hybrid system configuration

\section{B. Grid tied systems}

Various grid tied scheme are depicted in fig.2.5 and fig.2.6 The structure for specific site rely on geological, financial, and scientific factors $[14,15]$.

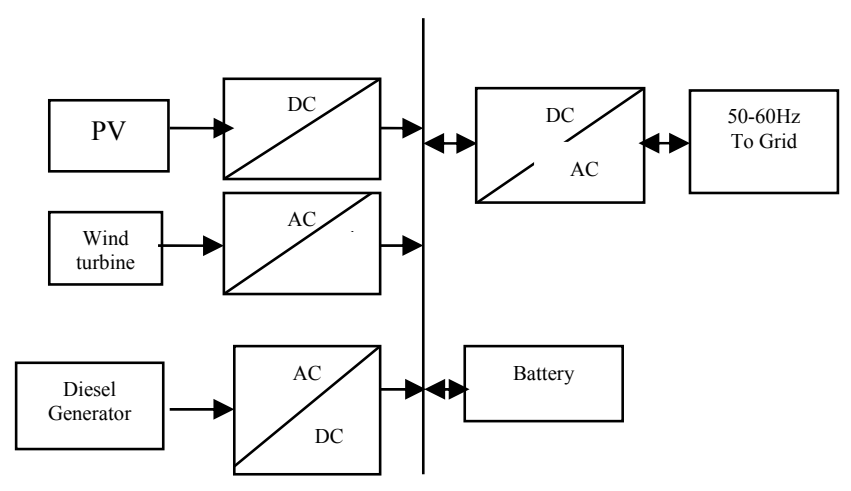

Fig 2.5 Centralized dc- bus

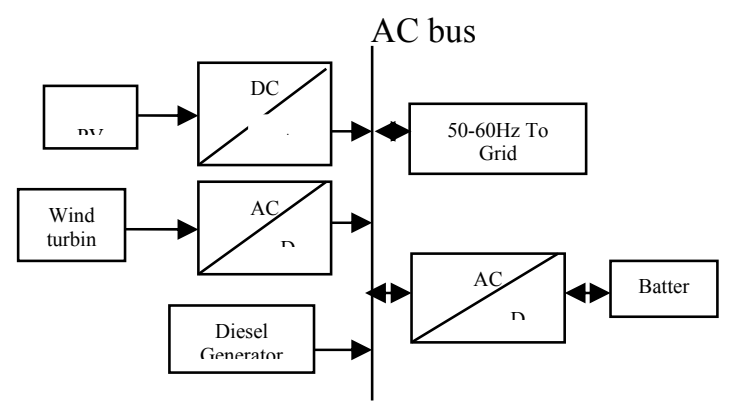

Fig 2.6 Centralized ac-bus
In this layout storage and source are connected at one site and is coupled to a prime ac link bus, by means of electronic devices [16]. A grid connection is also provided with filter.PLL technique is used to synchronize the two systems. In grid connected configuration it is not required to installed energy sources close to each other. [17]. The energy generated by several source is needed to be equivalent for different condition according to grid as depicted in fig.2.7 $[18,19]$.

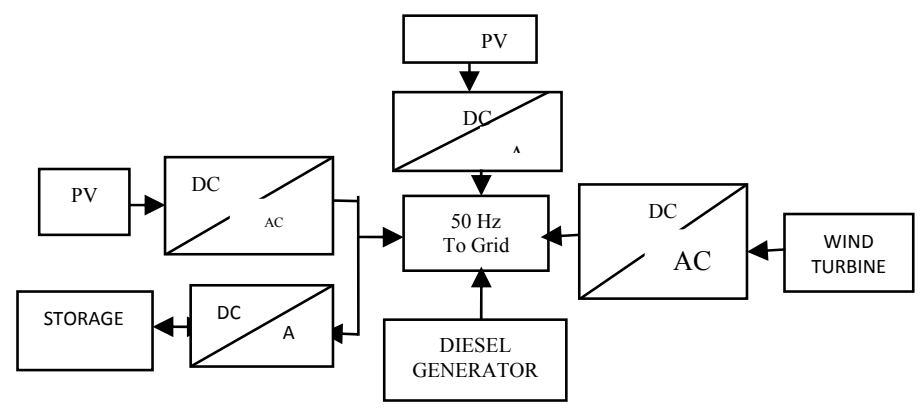

Fig 2.7 various standalone grid connected hybrid arrangement.

\section{Modeling of sustainable energy genesis}

\section{A. Modelling of wind conversion system}

Blades on the rotor convert wind kinetic energy into mechanical energy. This energy is transmitted by means of drive train to the alternator. The power of air flow at speed of $\mathrm{V}_{\mathrm{w}}$ passing through area of $\mathrm{A}$ can be determined

$$
\mathrm{P}_{\mathrm{w}}=\boldsymbol{\rho} \mathrm{A}
$$

Where $\boldsymbol{\rho}$ is the air density in $\mathrm{kg} / \mathrm{m}^{3}, \mathrm{~A}$ is the sweep area in $\mathrm{m}^{2}$ and $\mathrm{v}_{\mathrm{w}}$ is the wind speed in $\mathrm{m} / \mathrm{s}$. Normally near sea shore temperature of $15^{\circ} \mathrm{C}$ and air has density of approximately $1.2 \mathrm{~kg} / \mathrm{m}^{3}$.

And wind power grabbed by the blades converted to mechanical power can be measured by

$$
\mathrm{P}_{\mathrm{M}}=\boldsymbol{\rho} \mathrm{AC}_{\mathrm{p}}
$$

Where $C_{p}$ coefficient of power for wind blade. This coefficient of power for the modern age turbine lie between 0.19-0.49.

\section{B. Modeling of Micro hydro Energy system}

Energy captured from falling water which transfer its kinetic energy to the shaft in hydro power generation. This rotates the generator for the production of electricity. The power which can be generated in hydro plant in watts can be calculated by following formula

$$
P_{M H P S}=9.81 Q H_{n e t} \eta_{0} \rho_{W^{x}}
$$


where $\mathrm{Q}$ is the volume metre per second), $\mathrm{H}_{\text {net }}$ is the net height in metre available, $\rho_{\mathrm{W}}$ is the density of water, $\eta_{0}$ is the efficiency of hydro plant with turbine.

\section{Modeling of solar photovoltaic system}

Being more practical it is for the interest and analysis of performance that assessment should be done for maximum power. For the available radiation and suitable temperature calculation are done according to the manufacturing data available mentioned on the pv modules.

$$
\mathrm{P}_{\mathrm{PV}}=\eta_{\mathrm{g}} \mathrm{NA}_{\mathrm{m}} \mathrm{G}_{\mathrm{t}}
$$

Where, $g$ is efficiency of $\mathrm{PV}, \mathrm{A}_{\mathrm{m}}$ shows the area of a all cells perpendicular to irradiance $\left(\mathrm{m}^{2}\right)$.

\section{Modeling of fuel cell system}

This technique uses hydrogen-rich fuel to produce electron by use of two electrode. These electrode passes current to the load connected externally:

$$
2 \mathrm{H}_{2}+4 \mathrm{OH}^{-} \rightarrow 4 \mathrm{H}_{2} \mathrm{O}+4 \mathrm{e}^{-}
$$

Electrons are produced by reaction which can give electricity is an electrochemical process, and that can be taken through load. Fuel cell gives dc voltage which can be utilized in different use by inverting in to AC as well. Equation based on hydrogen fuel cell is mainly combustion reaction given below as:

$$
2 \mathrm{H}_{2}+\mathrm{O}_{2}=2 \mathrm{H}_{2} \mathrm{O}+\text { electrical energy }
$$

\section{E. Mathematical model of Tidal system}

The tidal energy modeling is identical to the wind model in various ways. Equation is used to model the turbine

$$
P_{m t}=\frac{1}{2} \eta \rho_{\text {water }} A_{T} v_{\text {water }}^{3}
$$

Where, $P_{m t}$ is the mechanical power used by the tides, $\rho_{\text {water }}$ is the density of water, $A_{T}$ is the tidal blade area $\left(\mathrm{m}^{2}\right), v_{\text {water }}$ is the speed of tides and $\eta$ is the efficiency. Cost of installation is much greater than life maintenance cost.

\section{Storage}

Storage option very essential for ensuring continuity of supply [20]. Various types of energy storage used in HRES [21]. Best solution for the storage used are batteries [22].

\section{A. Battery storage system}

Oldest electrical storage system is batteries which stores energy in form of chemical energy. It is environmental friendly and can be easily installed next to load. [23][24].

\section{B. Superconducting energy conversion (SMES) system}

This system stores magnetic energy initiated by the dc in coil associated with electronic device and cooled by it's below the superconducting critical temperature. It stores energy in the magnetic field, created by the flow of DC current in the superconducting coil [25].Considerable issue for the development of magnetic storage are high system cost and environmental requirement [26].

\section{Super capacitors energy storage}

Density level of super capacitor are higher as compare to batteries so these capacitor are connected in series which further connected in parallel with adjacent modules the voltage range of $180-480 \mathrm{~V}$ for safety and reliability point of view [27].

\section{Energy stored in flywheel}

In case of flywheel Energy stored depend upon directly to the square of the rotational speed and it's weight. Normally Flywheel energy storage released its energy when torque is applied to load [28][29]. Stored kinetic energy of flywheel is converted to electricity, when power is required. Flywheel efficiency varies from $75 \%$ to $90 \%$ [30-31].

\section{E. Pumped hydro storage (PHS)}

This technique of storage is very old having high performance. It repository time is very large. Normally it has two vertically separated reservoirs [32].Efficiency is in range of $55 \%-75 \%$ which depends upon the penstock size type of turbine and rating of generator for pumped storage. Pumped hydro system requires special geographical condition [33, 34].

\section{F. Compressed air energy storage (CAES)}

CAES is equivalent storage option having large capacity as pumped hydro storage of 60MW and above. The rating of CAES storage option lies between 05-350 MW [35, 36]. Its storage span is higher than other techniques which may be of one year and efficiency is in between 55-80\%[37-38].

\section{G. Hydrogen storage}

Hydrogen is originated by electrolysis process by usage of off-peak electrical power from renewable energy sources the hydrogen is generated by electrolysis process of water [39]. Fuel cells is key technology for portable and stationary power [40].

Various characteristics of each energy storage are given below: 
Table I: Aspects of the energy repository development

\begin{tabular}{|c|c|c|c|c|c|}
\hline ASPECT & PERFORMANCE & ADVANCEMENT & PRICE & $\begin{array}{c}\text { ENERGY } \\
\text { STORAGE }\end{array}$ & $\begin{array}{c}\text { POWER } \\
\text { STORAGE }\end{array}$ \\
\hline BATTERY & $80 \%$ & DEVELOPED & LESS & BIG & BIG \\
\hline PH & $80 \%$ & DEVELOPED & BIG & $\begin{array}{c}\text { SIZE } \\
\text { DEPENDENCE }\end{array}$ & $\begin{array}{c}\text { DEPEND UPON } \\
\text { HIGHT }\end{array}$ \\
\hline $\begin{array}{c}\text { FUEL } \\
\text { CELL }\end{array}$ & $55 \%$ & DEVELOPING & LESS & $\begin{array}{c}\text { HYDROZEN } \\
\text { DEPENDENCE }\end{array}$ & $\begin{array}{c}\text { DEPEND ON } \\
\text { FUEL }\end{array}$ \\
\hline FLYWHEEL & $85 \%$ & DEVELOPED & BIG & LESS & BIG \\
\hline SMES & $92 \%$ & DEVELOPING & BIG & LESS & BIG \\
\hline CAES & $70 \%$ & DEVELOPED & BIG & BIG & BIG \\
\hline
\end{tabular}

\section{Control Strategies}

In recent years, tremendous amount of work came into notice in area of sustainable energy sources. It seen that most of the researchers worked on two broad categories, i.e., design of HRES and performance of hybrid power system. A number of research papers related to modeling and control strategies are available through out literature. In this article, hybrid renewable energy models and control strategy are considered. In addition, various issues related to hybrid modeling are also addressed. This article is formed according to the approaches and methods adopted by different researchers to achieve an optimal hybrid design. Various performance optimization strategies are discussed here [42].

\section{A. Design Optimization}

The researchers worked under two broad optimization objectives [43]. One such category is the design of an optimal sizing of hybrid energy sources. This shows the selection of proper renewable energy sources with proper sizing, so that an optimized hybrid energy system could be developed, relying on the scope and feasibility of renewable power required of each source. By this technique one can design the capacity of sustainable system factors through optimizing the value of plant [44].

\section{B. Artificial intelligence (AI) approach}

There is no requirement of statistics for designing of combined power source in remote location when we use Artificial intelligence techniques [45]. Various techniques are available in research articles like PSO, artificial intelligence (ANN)[46], Genetic Algorithm (GA)[47], Grey wolf optimization (GWO)[48], honey algorithm, Blue whale optimization [49], fuzzy approach (FL), or a combination of any of above techniques. Genetic algorithm have also been widely used to optimize a hybrid system[50]. In such cases, Robust control has been widely used as compared to other artificial intelligence techniques.

\section{Iterative approach}

Sometimes iterative program approach is used to regulate the integrated energy system. And it ends up to optimal design is achieved. Many authors follow the storage option, PV panel ratings and wind rated power [51].

\section{Probabilistic approach}

This approach is used to design the size of HRES because it may change the parameter of renewable source. Probabilistic approach deals with radiation available and change in wind speed for the calculation of integrated system design. Dynamic variation of HRES cannot be identify by this techniques which is one of the disadvantage [52].

\section{E. Graphical construction method}

Various graphical optimization techniques have been reported in the literature. Only two variable were under consideration in this technique whether it is PV or Wind [53].

\section{F. Globally standard computer tools for designing}

HOMER is popular tool available for the sizing of HRES. This is done by decreasing the investment and increasing the use factor. Such software tools are for calculation of optimal performance on the basis of present cost [54].

\section{G. Performance optimization}

Only system sizing is not the matter of concern for the researchers. Thus, hybrid renewable energy systems need to be designed and controlled for the proper functioning of the system. Such controllers are responsible for the functioning of HRES at maximum power point, increasing the power quality, robust uninterrupted power supply, reduced internal losses and efficient cost effective power sharing among renewable energy sources in a hybrid system [55].

\section{H. Online control}

Real time simulators are also used for the analysis of power system now a day. In HIL simulation a prototype controller use only low power signals between a prototype controller and a plant [56].

\section{Operating point control}

Effort has also been done in controlling the operating point of the system keeping the system to work at MPP. Various operating point control algorithm is used for PVWind HRES to generate optimum energy to compensate the load demand[57].

\section{J. Converter control}

The characteristics of the renewable energy based system could be adjusted by controlling the converter parameters [58]. In case of single line to ground faults on the utility feeder without any storage device voltage source inverter (VSC) CAN control smooth operation in the system [59].

\section{K. HRES Control}

Power quality can be increased by the proper selection and management of HRES. Energy capturing option for the purpose of energy storage with a pair of hybrid magnetic bearings (HMBs); consisting of both superconducting magnetic bearings and active magnetic bearings applied with robust control method and zero bias method has also been developed [60].

\section{Conclusion}

An extensive review covering all the concerned aspects of HRES covering type's, storage, trends for research and control strategies of HRES has been presented. Sizing techniques algorithms implemented by various investigator for type of storage options are discussed. It has been observed that ANN techniques give relatively better result in order to find the reduced cost. Still It has been found much more work is required in this area of HRES; any how further exploration and attempts are mandatory to enhance power quality issues and storage option for their lower cost. In case of standalone 
condition load can result in transient condition which may collapse whole HRES. For such scenarios various optimization algorithm for controller of the HRES is to be carried out. It is also found that researchers have taken various control techniques for the development of hybrid energy system. Power quality, stability and power stability control have also been taken as the control objectives by various researchers. It is seen that large amount of work is done using conventional control techniques or power convertor control methods. The consequences of computational intelligence in different issue of HRES especially in the field of optimization and control has acquired enormous focus.

\section{REFERENCES}

[1] Nizar Aawar and Rahman, Arkadan, 'Optimal Control Strategy for Hybrid Electric Vehicle Power train' IEEE Journal of Emerging and Selected Topics in Power Electronics, Vol. 03, no. 2, June2015.

[2] P.K. Goel, Bhim Singh, Fellow, Isolated Wind Hydro Hybrid System Using Cage Generators and Battery Storage IEEE transactions on industrial electronics, vol. 58, no. 4, April 2011.

[3] Cheng-Wei Chen, Student Member, IEEE, Chien-Yao Liao, Student Member, IEEE, Kun-Hung Chen, and Yaow-Ming Chen, Senior Member, IEEE ' Modeling and Controller Design of a Semi isolated Multi input Converter for a Hybrid PV/Wind Power Charger System'IEEE transactions on power electronics, vol. 30, no. 9 , sep 2015.

[4] H.C. Chiang1 T.T. Ma1 Y.H. Cheng1 J.M. Chang2W.N. Chang 'Design and Implementation of a hybrid regenerative power system combining grid-tie and uninterruptible power supply functions' IET Renew. Power Gener., 2010, Vol. 4, Issue. 1, pp. 85-99.

[5] Md. Ibrahim, Abul Khair, Shaheer Ansari ' A Review of Hybrid Renewable Energy Systems for Electric Power Generation' Journal of Engineering Research and Applications ISSN: 2248-9622, Vol. 5, Issue 8, (Part - 1) August 2015, pp.42-48.

[6] Dada Delimustafic, Jasmina Islambegovic, Abdulah Aksamovic and Semsudin Masic 'Model of a Hybrid Renewable Energy System: Control', Supervision and Energy Distribution 1081-1086 IEEE.

[7] K K Prajapat, Abhishek Katariya Simulation and Testing of Photovoltaic with Grid Connected System 2011IEEE International Conference on Computational Intelligence and Communication Systems.

[8] Chunhua Liu, Member, IEEE, K. T. Chau, Senior Member, IEEE, and Xiaodong Zhang, Student Member, IEEE 'An Efficient Wind-Photovoltaic Hybrid Generation System Using Doubly Excited Permanent-Magnet Brushless Machine'IEEE transactions on industrial electronics, vol. 57, no. 3, march 2010.

[9] Swati Negi and Lini Mathew, ' Hybrid Renewable Energy System': A Review International Journal of Electronic and Electrical Engineering. ISSN 0974-2174, Volume 7, Number 5 (2014), pp. 535-542.

[10] Anurag Chauhan, R.P. Saini ' A review on Integrated Renewable Energy System based power generation for stand-alone applications: Configurations, storage options, sizing methodologies and control' Renewable and Sustainable Energy Reviews 38 (2014) 99-120.

[11] J.M. Lee* and B.H. Cho* Power System Structure and Control Strategy for Fuel Cell Hybrid Vehicle, 2008 IEEE.

[12] Jing Shi, Yuejin Tang, Lei Chen, Jin Wang, Li Ren, Jingdong Li, Liang Li, Tao Peng, and Shijie Cheng “ The
Application of Active Superconducting DC Fault Current Limiter in Hybrid AC/DC Power Supply Systems' IEEE transactions on applied uperconductivity, vol. 18, no. 2, june 2008.

[13] Fengge Zhang, Quanfu Shi, Yuxin Wang, Fengxiang Wang 'Simulation Research on Wind Solar Hybrid Power System Based on Fuzzy-PID Control' Proceeding of International Conference on Electrical Machines and Systems 2007, Oct. 8 11, Seoul, Korea.

[14] Swati Negi and Lini Mathew Hybrid Renewable Energy System: A Review International Journal of Electronic and Electrical Engineering. ISSN 0974-2174, Volume 7, Number 5 (2014), pp. 535-542.

[15] Ye Li and H. Keith Florig ' Modeling the Operation and Maintenance Costs of a Large Scale Tidal Current Turbine Farm'.Badoud, M. Khemliche 'Modelling. design and control of wind diesel hybrid power system using bond graph' 2013 IEEE.

[16] T. Aboul-Seoud, A. M. Sharaf Utilization of the Modulated Power Filter Compensator Scheme for a Grid Connected Rural Hybrid Wind/Tidal Energy Conversion Scheme 2010 IEEE Electrical Power \& Energy Conference.

[17] P.K.Ray, S.R. Mohanty, Nand Kishor Dynamic Modeling and Control of Renewable Energy Based Hybrid System for Large Band Wind Speed Variation 2015 IEEE.

[18] Md. Maruf-ul-Karim1, M. T. Iqbal 'Dynamic Modeling and Simulation of a Remote Wind Diesel-Hydrogen Hybrid Power System' 2010 IEEE Electrical Power \& Energy Conference.

[19] Chunhua Liu, Member, IEEE, K. T. Chau, Senior Member, IEEE 'An Efficient Wind-Photovoltaic Hybrid Generation System Using Doubly Excited PermanentMagnet Brushless Machine' IEEE transactions on industrial electronics, vol. 57, no. 3, march 2010.

[20] Jing Shi, Yuejin Tang, Lei Chen, Jin Wang, Li Ren 'The Application of Active Superconducting DC Fault Current Limiter in Hybrid AC/DC Power Supply Systems' IEEE transactions on applied superconductivity, vol. 18, no. 2, june 2008.

[21] Xiaoyu Wang and Meng Yue 'Modeling and Control System Design for an Integrated Solar Generation and Energy Storage System with a Ride-through Capability' 2012 IEEE.

[22] Puneet K. Goel, Bhim Singh, Senior Member IEEE Modeling and Control of Autonomous Wind Energy Conversion System with Doubly Fed Induction Generator2012 IEEE.

[23] Vigneshwaran Rajasekarani, Adel Merabee 'Maximum Power Point Tracking and Frequency Control for Hybrid Wind Diesel System Supplying anIsolated Load' 978-146732012 IEEE.

[24] Fezzani, I. Hadj Mahammed, and S. Said, 'MATLABBased Modeling of Shading Effects in Photovoltaic arrays' international conference on Sciences and Techniques of Automatic control \& computer engineering December 21-23, 2014.

[25] A.V. Pavan Kumar Alivelu M. Parimi K. Uma Rao Implementation of MPPT Control Using Fuzzy Logic in Solar-Wind Hybrid Power System' 978-1-4799/15/2015 IEEE.

[26] Nishad Mendis, Student Member, IEEE, Kashem M. Muttaqi, 'Operation of a Wind-Diesel- Battery based Hybrid Remote Area Power Supply System' 6th International Conference on Electrical and Computer Engineering ICECE 2010, 18-20 December 2010, IEEE.

[27] A. Andrijanovits, H. Hoimoja, D. VinnikovComparative Review of Long-Term Energy Storage Technologies for Renewable Energy Systems ELEKTROTECHNIK AISSN 1392 12152012. No. 2(118). 
[28] [29] Ajai Gupta*, R.P. Saini, M.P. Sharma Modelling of hybrid energy systemdPart I: Problem formulation and model development Renewable Energy 36 (2011) 459e4652010 Elsevier.

[29] ElectricalEnergyStorageInternationalElectrotechnicalCom missionISBN 978-2-88912-889-1[31] Jing Zhao, Zhongxin GuResearch on the Torque and Back EMF Performance of a High Speed PMSM Used for Flywheel Energy Storage Energies 2015, 8, 2867-2888ISSN 19961073.

[30] Hussein Ibrahimab, Adrian Ilincaa, Jean Perronb Comparison and Analysis of Different Energy Storage Techniques Based on their Performance Index2007 IEEE.

[31] M.A. Guerrero, E. Romero, Overview of Medium Scale Energy Storage Systems Power Electronics \& Electric Systems School of Industrial Engineering.

[32] A.M.ShiddiqYunus ' Overview of Storage Energy Systems for Renewable Energy System Application' 3rd Makassar International Conference on Electrical Engineering and Informatics (MICEEI 2012), Nov 28Dec 12012.

[33] Michelle Lim, Mohit Chhabra Frequency Variations in Hybrid Renewable Energy Network with Integrated Storage, Wide-Area Monitoring, Control \& Protection2011 IEEE.

[34] Paul Denholm, Erik Ela 'The Role of Energy Storage with Renewable Electricity Generation' Technical Report NREL/TP-6A2-47187 January 2010.

[35] B. Ould. Bilal Methodology to Size an Optimal StandAlone PV/wind/diesel/battery System Minimizing the Levelized cost of Energy and the $\mathrm{CO} 2$ Emissions ICAEE 2011: 27-28 December 2011, Bangkok, Thailand.

[36] Randa Kallel, Ghada Boukettaya, 'Control Management Strategy of Stand-Alone Hybrid Power Micro-System using Super-Capacitor' international journal of renewable energy research Randa Kallel et al., Vol.4, No.1, 2014.

[37] Madaci Mansour Case Study of a Solar Pumped Storage Prototype Station Implementation Designed for the Region of Ghardia INTERNATIONAL JOURNAL of RENEWABLE ENERGY RESEARC, Vol.6, No.2, 2016.

[38] Whei-Min Lin, Chih-Ming Hong 'Neural-Network-Based MPPT Control of a Stand-Alone Hybrid Power Generation System' IEEE transactions on power electronics, vol. 26, no. 12, december 2011.

[39] XIE Chang-jun and QUAN Shu-hai 'Control Strategy of Hybrid Power System for Fuel Cell Electric Vehicle based on Neural Network' Optimization Proceedings of the IEEE September 2008

[40] A.Hajizadeh, M.A.Golkar 'Fuzzy neural control of a hybrid fuel cell/ battery distributed power generation system' IET Renewable Power Generation March 2008.

[41] Taekwon Kim, Hyeon-jin Moon, Do-hoon Kwon, Seungill Moon 'A Smoothing Method for Wind Power Fluctuation Using Hybrid Energy Storage', Korea 978-14799- 7949-3/15/2015 IEEE.

[42] A.V. Pavan Kumar Alivelu M. Parimi K. Uma Rao "Implementation of MPPT Control Using Fuzzy Logic in Solar-Wind Hybrid Power System" 978-15/2015- IEEE.

[43] Sanjoy Debbarma Manas Bhattacharya Brijesh Kumar Meena Asim Datta "Frequency Control of Autonomous Hybrid Power System using Smart Controllable Load", Shillong India ISBN: 978-81-925974-3-0/2015.

[44] Sukhwinder Singh Dhillon Sanjay Marwaha Jagdeep Singh Lather "Robust Load Frequency Control of Micro Grids Connected with Main Grids in a Regulated and Deregulated Environment" 978-1-4799-4040-0/14/2014 IEEE.

[45] Arash Jamehbozorg Yanzhu Ye, Ratnesh Sharma "A Robust Control Approach to Smooth Output Power of Wind Units Using Hybrid Storage Systems Considering State of Charge" 978-1-4799-3656-4/14/2014 IEEE.
[46] Swati Rawat Shailendra Singh Kshitij Gaur "Load Frequency Control of a Hybrid Renewable Power System with Fuel Cell System" 978-1-4799-6042-2/14/2014 IEEE.

[47] T.Praveen Kumar, N. Subrahmanyam, M. Sydulu "Unit Power Control and Feeder Flow Control Strategies for a Grid-Connected Hybrid System" 2013 International Conference on Power, Energy and Control (ICPEC), 9781-4673-6030-2/13/2013 IEEE.

[48] S. Srinivas Narsa Reddy Tummuru, Mahesh K. Mishra "Integration of PV/Battery Hybrid Energy Conversion System to the Grid with Power Quality Improvement Features", and, IEEE 978-1-4673-4569-9/13/2013 IEEE 2013 Eighth International Conference and Exhibition on Ecological Vehicles.

[49] Abderrezzak BouharchoucheEI Madjid Ghennam Berkouk Tarrak "Renewable Energies EVER)Control and Energy Management of a Grid Connected Hybrid Energy System PV -Wind with Battery Energy Storage for Residential Applications" 1 978-1-4673-5271-0/13/2013 IEEE.

[50] Surya Prakash and S K Sinha "Four Area Load Frequency Control of Interconnected Hydro- thermal Power System by Intelligent PID Control Technique" 978-1-4673-04559/12/2012 IEEE.

[51] Meena Tushir Smriti Srivastava "Application of a Hybrid Controller in Load Frequency Control of Hydro-Thermal Power System" 978 -1-4673-0766-6/12/2012 IEEE.

[52] Mousa Marzband Andreas Sumper Mircea Chindris "Frequency Control of Isolated Wind and Diesel Hybrid Micro Grid Power System by Using Fuzzy Logic Controllers and PID Controllers" 978-1-4673-03781/11/2011 IEEE.

[53] R.Dhanalakshmi S.Palaniswami "Application Of Multi Stage Fuzzy Logic Control For Load Frequency Control Of An Isolated Wind Diesel Hybrid Power System" 9781-4673-0178-7/11/2011 IEEE.

[54] T. R. Mtshali, G. Coppez, S.Chowdhury, S.P. Chowdhury "Simulation and Modelling of PV-Wind-Battery Hybrid Power System" 978-1-4577-1002-5/11/2011 IEEE 2010 IEEE International Energy Conference.

[55] Nishad Mendis, Kashem M. Muttaqi, Saad Sayeef "Application of a Hybrid Energy Storage in a Remote Area Power Supply System" 978-1-4244-9380-7/10/2010 IEEE.

[56] Nishad Mendis, Kashem M. Muttaqi, Saad Sayeef Operation of a "Wind-Diesel-Battery based Hybrid Remote Area Power Supply System" 6th International Conference on Electrical and Computer Engineering ICECE2010,18-20 December 2010, Dhaka, 978-1-42446279-7/10/2010 IEEE.

[57] David Hern andez-Torres, Delphine Riu, Olivier Sename and Florence Druart "Robust Optimal Control Strategies for a Hybrid Fuel Cell Power Management System" 9781- 4244-5226-2/10/2010 IEEE.

[58] Puneet K. Goel, Bhim Singh S.S. Murthy "Autonomous Hybrid System Using SCIG for Hydro Power Generation and Variable Speed PMSG for Wind Power Generation",PEDS2009.

[59] Gerard Robert, Dominique Hurtado "Optimal Design of Reactive Power PI Regulator for Hydro Power Plants" 17th IEEE International Conference on Control Applications Part of 2008 IEEE Multi-conference on Systems and Control San Antonio, Texas, USA, September 3-5, 2008978-1-4244-2223-4/08/2008 IEEE.

[60] G. Robert, JL. Planque "Robust Digital Automatic Reactive Power Regulator for Hydro Power Plants", 14244-0632-3/07/2007 IEEE. 